\title{
6. PALEOGENE LARGER FORAMINIFER BIOSTRATIGRAPHY FROM LIMALOK GUYOT, SITE $871^{1}$
}

\author{
Alda Nicora, ${ }^{2}$ Isabella Premoli Silva, ${ }^{2}$ and Annie Arnaud Vanneau ${ }^{3}$
}

\begin{abstract}
About $290 \mathrm{~m}$ of shallow-water carbonate limestone, mainly of early to middle Eocene age, was drilled at Site 871, which is in the center of Limalok Guyot. The limestone was below more than $130 \mathrm{~m}$ of pelagic sediment and a thin manganese-rich crust. Despite the poor recovery, recovered sediments were rich in age-diagnostic larger benthic foraminifers, primarily belonging to the genera Alveolina and Nummulites.

Flooding of the volcanic island occurred during the early late Paleocene as indicated by sparse, depauperate calcareous nannofossil assemblages preserved in association with dark gray aragonitic grainstones. This implies that open-marine conditions existed during the initial stages of inundation.

A substantial carbonate platform became established, possibly during the latest Paleocene. This platform complex persisted throughout the early Eocene into the early middle Eocene. Faunal and floral assemblages indicate that the evolution of Limalok platform was complex, with several fluctuations of water depth. Three distinct paleoecological assemblages, with some subassemblages, developed during the course of the platform's evolution; larger foraminifers and red algae often played a major role in the paleocommunity. Paleoenvironmental conditions in the central lagoon varied from deeper water and well oxygenated, to restricted and poorly oxygenated. There was at least one period of open-marine influx. More open-marine conditions resumed at Site 871 in the early middle Eocene, just before the drowning of the platform in the middle middle Eocene. The hiatus between the youngest shallow-water carbonates and the oldest calcareous plankton preserved in the overlying Mn-crust is estimated to not exceed 3-4 m.y.
\end{abstract}

\section{INTRODUCTION}

Paleogene larger benthic foraminifers were recovered from shallow-water limestones drilled at Limalok (Harrie) Guyot (Site 871) in the Ratak Chain of the southern Marshall Islands (see site map preceding title page). This site is centrally located on the summit of the guyot at $5^{\circ} 33.43^{\prime} \mathrm{N}, 172^{\circ} 20.67^{\prime} \mathrm{E}$ at $1255 \mathrm{~m}$ below sea level (mbsl) (Premoli Silva, Haggerty, Rack, et al., 1993). Three holes were drilled at Site 871 . Holes $871 \mathrm{~A}$ and $871 \mathrm{~B}$ ended just at the top of the carbonate platform. At Hole $871 \mathrm{C}$, about $290 \mathrm{~m}$ of the shallow-water limestones was drilled from 133.7 to $422.9 \mathrm{~m}$ below seafloor (mbsf) before a clayey unit resting on basaltic breccias and flows was encountered (Fig. 1).

Shallow-water limestones previously were dredged from the edge of Limalok Guyot and dated as early Eocene (Schlanger et al., 1987). Moreover, a rather rich shallow-water foraminifer fauna of late Paleocene to early Eocene age, consisting of several species of Nummulites, rare Assilina, and a single specimen of Alveolina from transported sediments, was recovered at Deep Sea Drilling Project (DSDP) Hole 462A, which was drilled in the Nauru Basin, located west of Limalok Guyot (Premoli Silva and Brusa, 1981).

This study deals mainly with larger foraminifers from Hole 871C. The identification and distribution of these foraminifers allowed us to date the carbonate succession. Some efforts also were dedicated to the paleoecological reconstruction and environmental evolution of the Limalok carbonate sequence using benthic foraminifer content and other associated organisms, including very rare planktonic foraminifers.

\footnotetext{
'Haggerty, J.A., Premoli Silva, 1., Rack, F., and McNutt, M.K. (Eds.), 1995. Proc. ODP, Sci, Results, 144: College Station, TX (Ocean Drilling Program).

${ }^{2}$ Dipartimento di Scienze della Terra, Università di Milano, via Mangiagalli 34, 20133 Milano, Italy.

${ }^{3}$ Institut Dolomieu, Université de Grenoble, rue Maurice Gignoux, 30031 Grenoble Cedex, France.
}

\section{MATERIALS AND METHODS}

More than 100 rock samples and "cuttings" were studied from Holes 871A, 871B, and 871C. The identification of microfauna and associated organisms from the platform carbonates at Site 871 was determined mainly on the basis of thin-section and acetate-peel examination. Some whole isolated specimens also were recovered as "cuttings" (debris of limestones collected on a sieve as each section of the core was split), and a few oriented thin sections of some macroforaminifers were made to analyze the internal and embryonic characters. The "cuttings" samples listed in Table 1 are plotted below the lowermost centimeter recovered in any specific section.

Table 1 shows the distribution and abundance of benthic foraminifers, as well as selected sedimentological features. The distribution of all the identified organisms are plotted in Figure 2 as abundance curves. Some of the most important benthic foraminifers and a few microfacies are illustrated in Plates 1 through 4.

\section{BIOSTRATIGRAPHIC EVENTS AND AGE ATTRIBUTION}

The record of organisms from Site 871 is scattered throughout the drilled sequence. This is related to (1) the very poor recovery, which prevented the depiction of the true distribution of organisms and facies, and (2) the fact that the carbonate platform succession recovered at Limalok experienced several changes in facies deposition, which resulted in poor assemblages in some intervals.

From a biostratigraphic point of view, age-diagnostic organisms are confined to the larger foraminifers, especially alveolinids and nummulitids and to a minor extent, asterocyclinids, discoscyclinids, and coskinolinids, occurring in specific intervals or samples. For zonal identification and age attribution, we refer to the zonation scheme of Hottinger (1960), Drobne (1977), Hottinger and Drobne (1988), and White (1992) for the alveolinids, and we use that of Schaub (1981) and Kleiber (1991) for nummulitids and correlation between alveolinid 
Table 1. Stratigraphic ranges and relative abundance of latest Paleocene to middle Eocene larger foraminifers and sedimentary features from shallowwater limestones drilled in Holes 871A, 871B, and 871C (summit of Limalok Guyot).

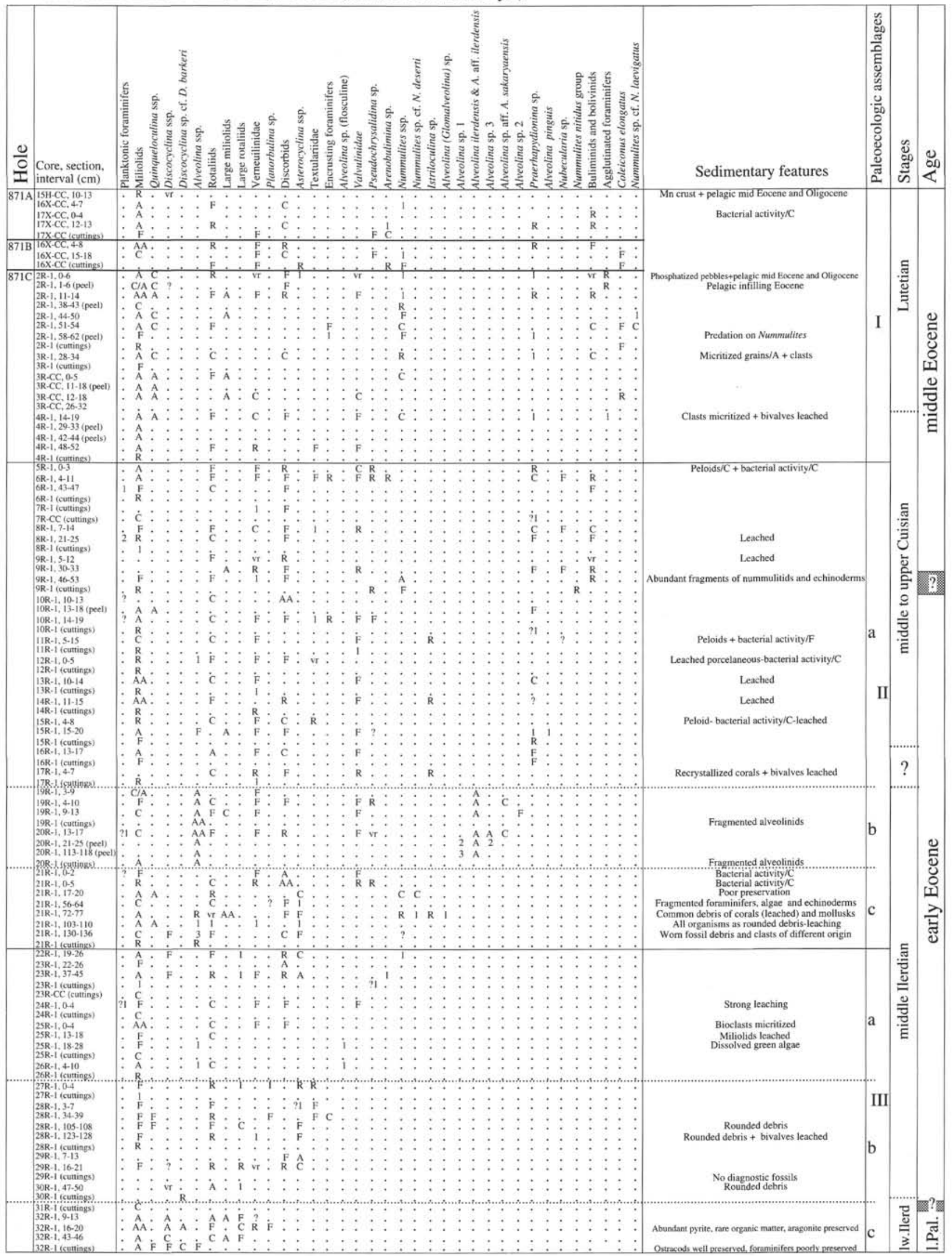

Notes: Estimated abundance indicated as follows: $=$ number of specimens, $\mathrm{vr}=$ very rare, $\mathrm{R}=$ rare, $\mathrm{F}=\mathrm{few}, \mathrm{C}=\mathrm{common}, \mathrm{A}=\mathrm{abundant}$, and $\mathrm{AA}=\mathrm{very}$ abunant. 
and nummulitid zones to calcareous nannofossils (see Premoli Silva, Haggerty, Rack, et al., 1993). The larger foraminifer zonal schemes refer to classical stages. The correlation and calibration of PaleoceneEocene stages to plankton scales are presently under revision by International Geological Correlation Programme (IGCP) Projects 286 and 308. Therefore, the age attributions in this paper must be considered as the actual best estimate. Brief taxonomic remarks of some larger foraminifer species are given later in the paper.

The following foraminiferal events were recognized (from oldest to youngest) (Fig. 1 and Table 1).

1. The occurrence of Alveolina sp. in the "cuttings" sample of Section 144-871C-32R-1 indicates that the lowermost shallow-water carbonate sediments cannot be older than the Ilerdian, the base of which falls within the planktonic foraminifer Zone P5 and nannofossil Zone CP8 (Hottinger, 1960; Schaub, 1981; Berggren et al., 1985; Kleiber, 1991). Common specimens of Discocyclina sp. cf. D. barkeri are associated with the alveolinids in the same sample and also occur in Sample 144-871C-32R-1, 16-20 cm. This species is known from the Caribbean region in Paleocene to lower Eocene strata (Ellis and Messina, 1967), and its occurrence at the bottom of Hole 871C is consistent with the presence of alveolinids. The latest Paleocene age based on larger foraminifers is definitely younger than that inferred from calcareous nannofossils. The assemblages recorded in Samples 144-871C-32R-1, 10-90 cm, and -31R-1, 47-48 cm, were attributed, even with some uncertainty, to Zone CP 5 of Okada and Bukry (1980) and dated as early late Paleocene (see Premoli Silva, Haggerty, Rack, et al., 1993).

2. Common Asterocyclina sp. occur in Samples 144-871C-29R$1,16-21 \mathrm{~cm}$, and $-29 \mathrm{R}-1,7-13 \mathrm{~cm}$. According to Less (1987), this genus first appears in the middle Ilerdian, or in the early Eocene in term of calcareous plankton (Schaub, 1980; Kleiber, 1991).

3. Two specimens of strongly flosculinized Alveolina sp. occur in Samples 144-871C-26R-1, 4-10 cm, and -25R-1, 18-28 cm. According to Hottinger (1960) and Hottinger and Drobne (1988), flosculine alveolinids appear close to the base of the Ilerdian.

4. One specimen of Nummulites $\mathrm{sp}$. cf. $N$. deserti was recovered in Sample 144-871C-21R-1, 72-77 cm, together with one individual of A. (Glomalveolina) sp. The appearance of the genus Nummulites, and specifically $N$. deserti, marks the base of the Ilerdian. $N$. deserti ranges up to the middle part of middle Ilerdian.

5 . The presence of numerous Alveolina ilerdensis in Samples 144-871C-20R-1, 113-118 cm, through -19R-1, 3-9 cm, indicates that these cores cannot be older than the middle upper part of the middle llerdian. This attribution is confirmed by the occurrence of Alveolina sakaryaensis, a species confined to the middle Ilerdian, in Samples 144-871C-20R-1, 13-17 cm, and -19R-1, 4-10 cm. Cores 144-871C-20R and -19R, then, are early Eocene in age.

6. One specimen of Alveolina pinguis was identified in Sample 144-871C-15R-1, 15-20 cm. According to Hottinger (1960) and Hottinger and Drobne (1988), A. pinguis appears in the uppermost part of the Alveolina dainellii Zone and ranges up through the Alveolina violae Zone, indicating the upper middle to upper Cuisian. In terms of the calcareous plankton, this event is middle early Eocene in age.

7. A few isolated Nummulites from Section 144-871C-9R-1 were identified as belonging to the $N$. nitidus group (Fig. 3). N. nitidus appears at the base of the middle Cuisian, but $N$. aff. nitidus is transitional to the descendant species $N$. formosus and ranges as high as the upper Cuisian (Schaub, 1981). According to Schaub (1981) and Kleiber (1991), the base of the upper Cuisian is equated to the base planktonic foraminifer Zone P10, which is considered the lowermost zone of the middle Eocene in terms of calcareous plankton (Berggren et al., 1985).

8. The occurrence of a high-spired planktonic globigerinid form, now identified as belonging to the Guembelitrioides higginsi group (Sample 144-871C-8R-1, 21-25 cm) is consistent with the age based on Nummulites of the underlying core. Guembelitrioides higginsi

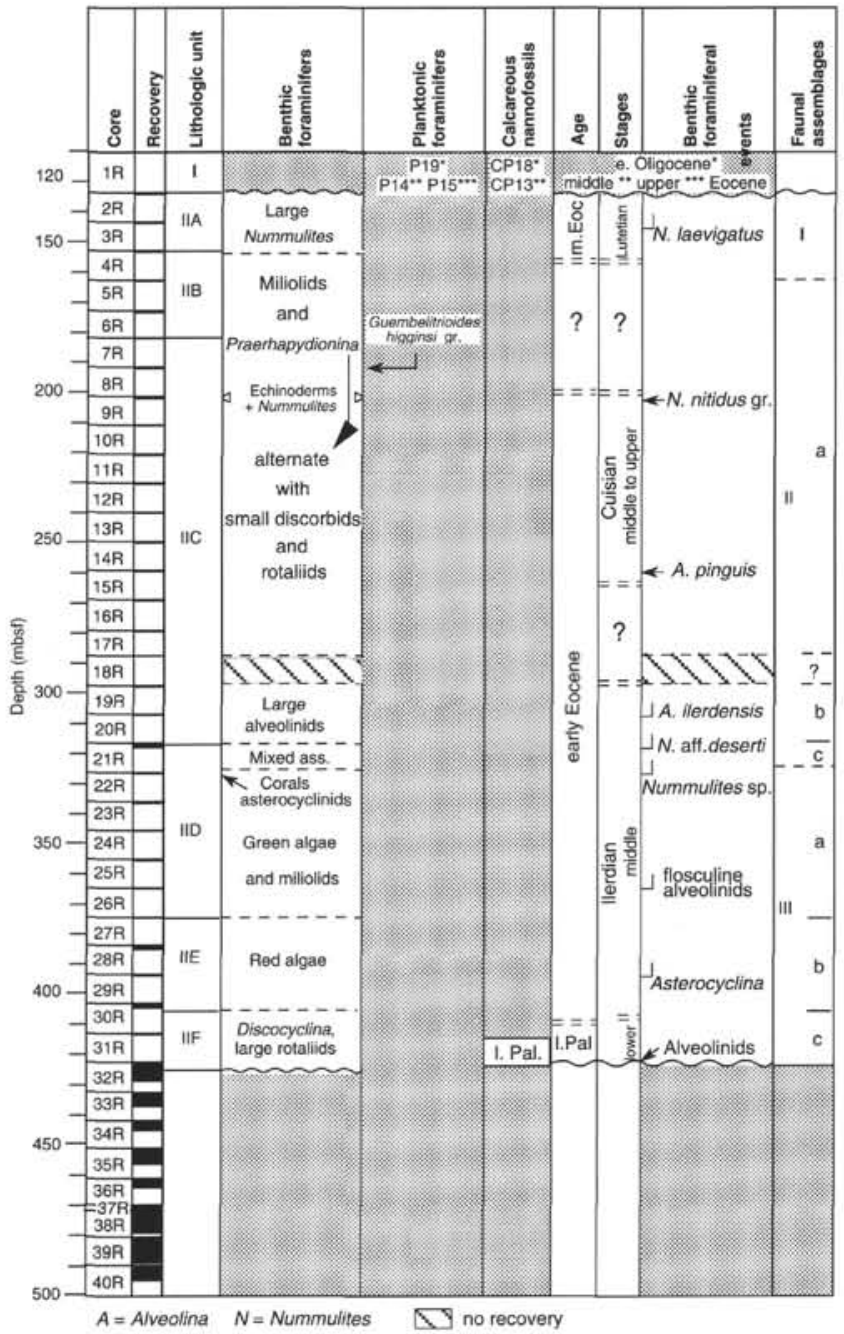

Figure 1. Synthetic log of shallow-water limestones drilled in Hole 871C (Limalok Guyot) with core recovery, lithologic units, characteristic fossil content, larger foraminifer occurrences, and paleoecological assemblages plotted vs. calcareous plankton occurrence, stages, and age.

appears at the base of Zone P9 and extends through the lower middle Eocene Zone P11 (Toumarkine and Luterbacher, 1985).

9. The appearance of $N$. laevigatus in Core 144-871C-2R identifies the Nummulites laevigatus Zone, equated to the base of the Lutetian, of early middle Eocene age (Schaub, 1981). N. laevigatus co-occurs with Coleiconus elongatus, which ranges from the upper lower to lower middle Eocene (see Ellis and Messina, 1967). Its occurrence then corroborates the age indicated by Nummulites and suggests that the top of the carbonate platform is not younger than early middle Eocene.

10. The Mn-crust, sealing the shallow-water carbonate succession at Site 871 , yielded a nannofossil assemblage attributable to Zone CP13 of middle middle Eocene age and a well diversified planktonic foraminifer assemblage of Zone P14 of late middle Eocene age (see Fig. 1). This suggests that the carbonate platform was under a pelagic regime shortly after its demise in the middle Eocene.

In summary, marine sedimentation at Limalok initiated in the early late Paleocene, as indicated by the calcareous nannofossils of Zone CP5 in the lowermost core. However, the first evidence of shallowwater carbonate sedimentation is of much younger age. The identification of Alveolina sensu stricto in the same samples yielding the calcareous nannofossil assemblage mentioned above suggests that the shal- 


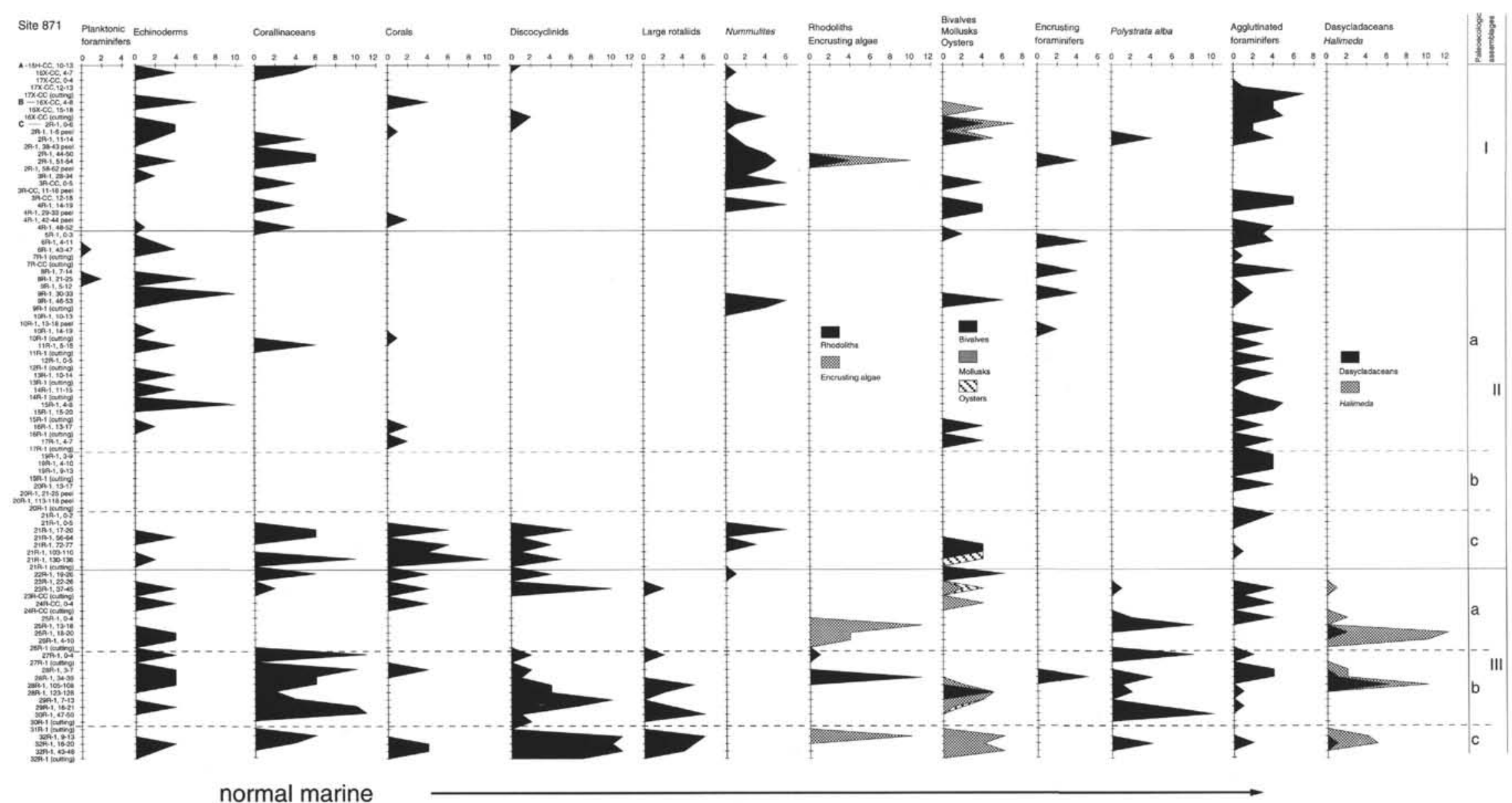

Figure 2. Abundance curves of the organisms from the shallow-water carbonate succession recovered at Limalok Guyot (Site 871), arranged according to paleoenvironmental significance (normal marine on the left to more restricted on the right). Samples as in Table 1 . Organism abundance was estimated as follows: $1=$ one individual or fragment; $2=2-3$ individuals or fragments; $3=4-5$ individuals or fragments; 4 $=6-7$ individuals or fragments; $5=8-9$ individuals or fragments; $6=$ common individuals or fragments; $7=$ common to frequent individuals or fragments; $8=$ frequent individuals or fragments; $9=$ frequent to abundant individuals or fragments; 10 = abundant individuals or fragments; 11 = very abundant individuals or fragments; and $12=$ extremely abundant individuals or fragments. 


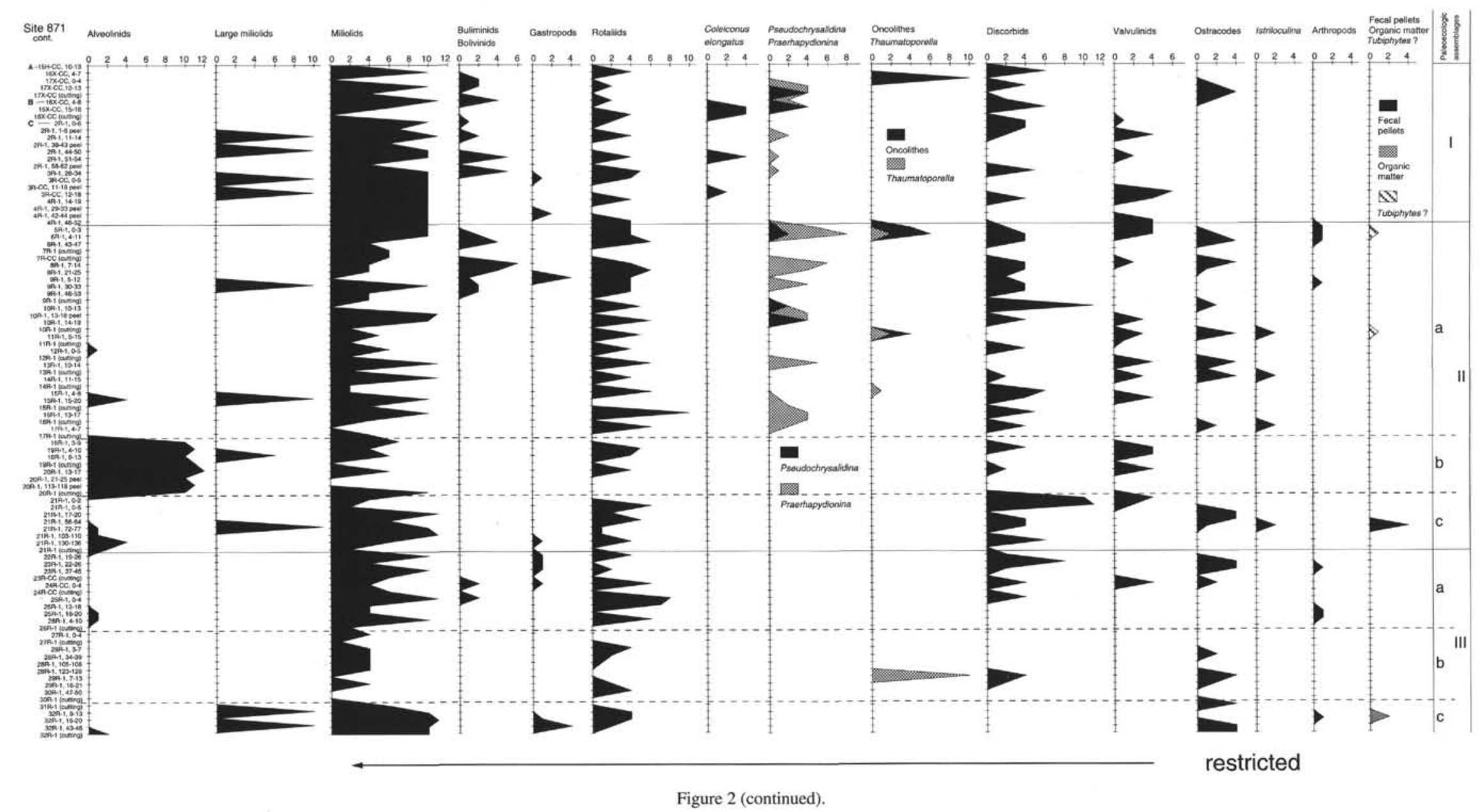



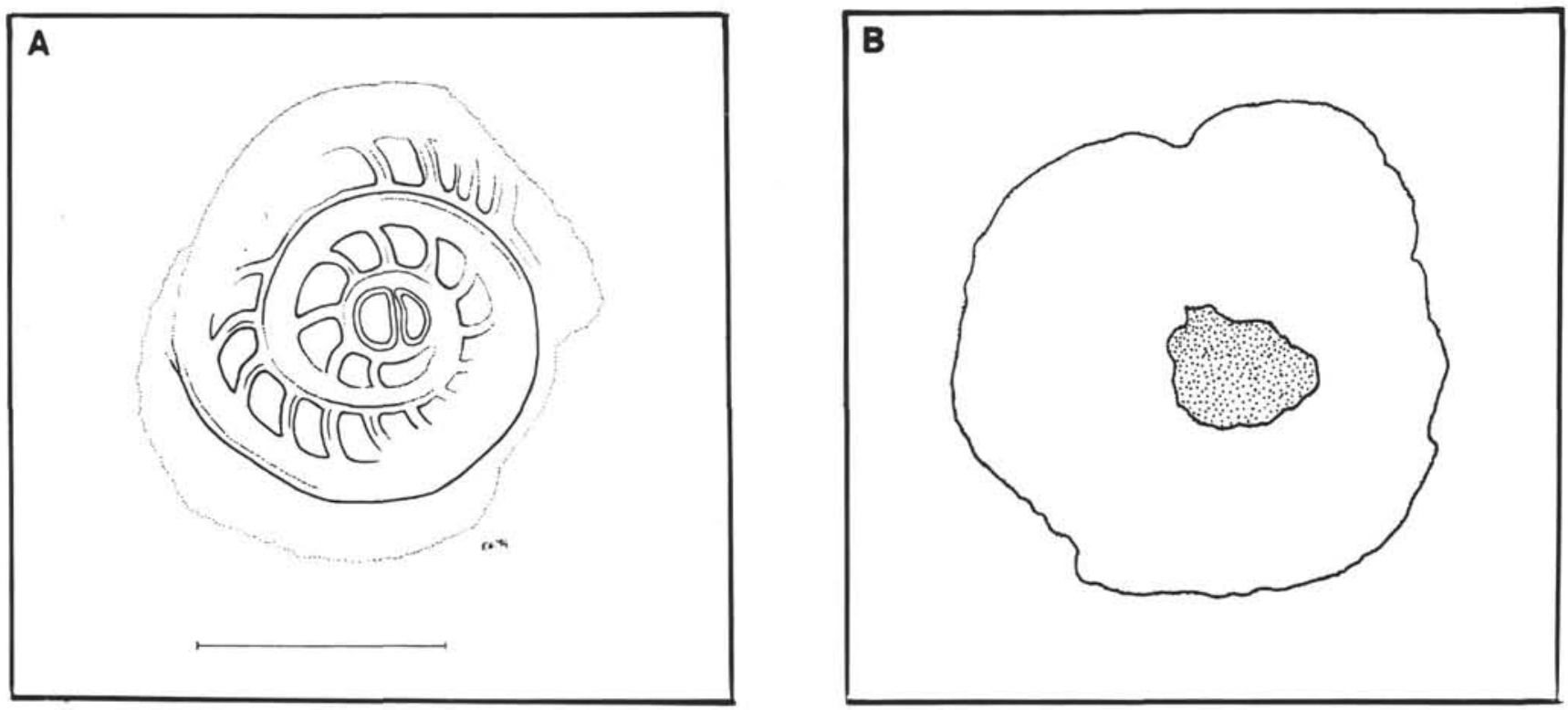

Figure 3. Nummulites sp. aff. N. nitidus. Sketches of the inner spire (A) and external side (B) of the same recrystallized specimen derived from photographs. Section 144-871C-9R-1, "cuttings"; bar = 1 mm.

low-water carbonate platform at Limalok did not develop before the Ilerdian, which means not before the latest Paleocene planktonic foraminifer Zone P5. Thereafter, carbonate sedimentation continued to develop until its demise, dated to the early middle Eocene, apparently without major hiatus.

Although the scattered record of alveolinids and nummulitids prevented the application of the zonal schemes of Hottinger (1960) and Schaub (1981), the recognized events among these larger foraminifers seem to occur in stratigraphic order (Fig. 1 and Table 1). This permits us to document with some certainty (1) the middle Ilerdian, from the appearance of Asterocyclina in Cores 144-871C-29R through -19R, which also yielded numerous Alveolina ilerdensis, a species not ranging beyond the middle Ilerdian; (2) the upper middle and upper Cuisian, although based on the punctual occurrence of Alveolina pinguis in Core 144-871C-15R and representatives of the Nummulites nitidus group in Core 144-871C-9R; and (3) the basal Lutetian, based on the occurrence of Nummulites laevigatus in Cores 144$871 \mathrm{C}-3 \mathrm{R}$ and $-2 \mathrm{R}$ at the top of the carbonate succession.

Conversely, the placement of the Paleocene/Eocene and lower/ middle Eocene boundaries is problematic mainly because of the uncertain correlation between stage boundaries and calcareous plankton scale. Tentatively, the Paleocene/Eocene boundary could fall between Cores 144-871C-31R and -29R, if it is accepted that the oldest assemblage is latest Paleocene in age, which is not fully proven. The lower/ middle Eocene falls before Core 144-871C-3R, but we lack any evidence for constraining its position below (above Core 144-871C-9R?).

The lack of evidence for some intervals is attributed either to poor recovery or to unsuitable facies for diagnostic benthic foraminifers or both, although interruption of sedimentation by minor hiatuses cannot be ruled out. Core 144-871C-21R displays evidence of some reworking, as suggested by the co-occurrence of facies and fossils of different environments (see discussion below; Arnaud Vanneau et al., this volume).

\section{PALEOECOLOGICAL INTERPRETATION}

From a paleoecological point of view, the foraminifer-algal-macrofossil assemblages recovered in Hole $871 \mathrm{C}$, and to a minor extent in Holes $871 \mathrm{~A}$ and $871 \mathrm{~B}$, reflect shallow-water platform environments ranging from a somewhat-restricted lagoon to a fully normal marine environment. This interpretation is supported by the fluctuations through the recovered succession in diversity and abundance of the whole micro- and macrofauna and flora. Higher diversity assemblages indicate more open marine conditions and vice versa. The overall diversity and estimated abundance of the various fossil groups, identified in each sample, are shown in Figure 2. Despite the poor to very poor recovery of the fossil assemblages, three major associations could be distinguished (from bottom to top).

\section{Paleoecologic Assemblage III}

Sample 144-871C-32R-1, $46 \mathrm{~cm}$, and "cuttings," to Sample 144-871C22R-1, 19-26 cm (= lithologic Subunit IIF through most of Subunit IID)

This assemblage is highly diverse and dominated by the activity of red algae that occurs as rhodoliths, algal carpets, or branched forms. More specifically (see Fig. 2), in the lowermost samples, Subassemblage IIIc is characterized by encrusting algae, especially Melobesiae, associated with common to abundant discocyclinids, common large rotaliids, and abundant miliolids. Rare small alveolinids and few Halimeda (still aragonitic in Sample 144-871C-32R-1, $16-20 \mathrm{~cm}$ ) are also present. Other components are common mollusks, few corals, echinoderms, gastropods, and ostracods.

Subassemblage IIIb is totally dominated by diverse calcareous algae associated consistently with asterocyclinids and few large rotaliids. Crustose melobesian algae are the most abundant component throughout, although rhodoliths are dominant in some levels (e.g., Sample 144-871C-28R-1, 34-39 cm). Other algal taxa include dasycladaceans with the genera Cymopolia and Salpingoporella, Polystrata alba, Halimeda, and Thaumatoporella, which are only occasionally abundant. Among the benthic foraminifers, Asterocyclina and large rotaliids are more common in the lower samples; Discocyclina and miliolids are rare throughout. The macrofauna comprises sparse corals, rare to few echinoids, bivalves, and ostracods.

Subassemblage IIIa is characterized again by common encrusting algae, Polystrata alba, and Halimeda (especially in the lower samples), common to abundant miliolids, few to common small rotaliids, and few discorbids. Also noted was the presence of asteroyclinids, corals, and mollusks in the upper samples. Two specimens of alveolinids are recorded in Samples 144-871C-26R-1, 4-10 cm, and -25R$1,18-28 \mathrm{~cm}$. 


\section{Paleoecologic Assemblage II}

Sample 144-871C-21R-1, 136-138 cm, and "cuttings," to Sample 144-871C-5R-1, 0-3 cm (= uppermost part of lithologic Subunit IID through the middle third of Subunit IIB)

Assemblage II is characterized by the consistent occurrence of species indicative of a lagoonal, more-to-less restricted environment (Fig. 2). Three subassemblages were distinguished. Subassemblage IIc, represented in Core 144-871C-21R, is characterized by its overall poor fossil preservation. Numerous forms are fragmented, worn, and micritized; they occasionally appear included in clasts. Mechanical transport and reworking are inferred. The most consistent components are abundant Asterocyclina, common to abundant miliolids, corals, and melobesian algae. Miliolids of remarkable large size are present in Sample 144-871C-21R-1, 72-77 cm. Rare to few minute alveolinids occur in the lower samples, whereas few to common Nummulites are recorded in the upper samples. Corals occasionally were recovered as whole specimens (Sample 144-871C-21R-1, 69$92 \mathrm{~cm}$ ). Other foraminifers include rare Discocyclina, agglutinants, and a few small rotaliids and discorbids. Microbial activity was detected in some layers of the upper samples. The uppermost samples (144-871C-21R-1, 0-2 cm, and -21R-1, 0-5 cm) yielded very poor assemblages, indicating a more restricted environment.

Subassemblage IIb is typically largely dominated by mediumsized alveolinids that exhibit medium flosculinization. Few miliolids and small benthic (agglutinated, rotaliids, valvulinids) foraminifers are the few accompanying organisms. Calcareous algae and megafossils are remarkably absent.

Subassemblage IIa is characterized by typical lagoonal assemblages with abundant miliolids, whereas larger foraminifers are almost absent. The environmental conditions varied from restricted (characterized by the presence of Istriloculina, discorbids, small rotaliids, and Thaumatoporella with more or less developed bacterial activity) to less restricted facies (with abundant miliolids and Praerhapydionina). Short episodes of more open-marine influence affected the lagoon within this interval. These are indicated by the occurrence of a single specimen of Alveolina (Samples 144-871C-15R-1, 15-20 cm, and -12R-1, 0-5 $\mathrm{cm}$ ), few Nummulites (Samples 144-871C-9R-1, 30-33 and 48-53 cm), very rare planktonic foraminifers (Guembelitrioides higginsi group and Chiloguembelina sp. in Samples 144-871C-8R-1, 21-25 cm, and $-6 \mathrm{R}-1,43-47 \mathrm{~cm}$ ), and more commonly by abundant echinoderm debris in Cores 144-871C-15R, -9R, and -6R. A whole echinoid specimen was recovered from Sample 144-871C-9R-1, 0-5 cm.

\section{Paleoecologic Assemblage I}

Samples 144-871A-16X-CC, 4-7 cm, to $-17 \mathrm{X}-\mathrm{CC}, 12-13 \mathrm{~cm}$, and "cuttings"; Samples 144-871B-16X-CC, 4-8 cm, to -16X-CC, 15$18 \mathrm{~cm}$, and "cuttings"; Samples 144-871C-2R-1, 0-6 cm, to -4R-1, $48-52 \mathrm{~cm}$, and "cuttings" (= upper third of lithologic Subunit IIB through Subunit IIA)

This assemblage is characterized by large foraminifers (e.g., some "pillared" Nummulites), common to abundant large miliolids, and Coleiconus elongatus, associated with few to common red algae, some bivalves, well-diversified small benthic foraminifers, and rare corals.

\section{Interpretation}

According to the modern depth distribution of larger foraminifers and associated organisms from warm-water environment such as the Gulf of Aqaba (e.g., Hottinger, 1983; Reiss and Hottinger, 1984), the assemblages listed above can be interpreted in paleoecological terms and estimated relative water depth. In an ideal transect from shallow to deep, the following sequence at Site 871 would apply:

1. The most restricted environmental conditions of the entire sequence from Limalok Guyot occurred at the top of Core 144-871C-
21R (included in Subassemblage IIc), as demonstrated by the very poor assemblage found in this interval.

2. A relatively shallow lagoonal environment was associated with Subassemblage IIa, characterized by an alternation of assemblages rich in miliolids proliferating under more oxygenated conditions and those rich in discorbids and small rotaliids under less oxygenated conditions, respectively. Also some facies in Subassemblage IIIa (Core 144-871C-23R) possibly indicate a similar environment.

3. Subassemblage IIlb, characterized by abundant alveolinids, indicates a lagoonal environment but in slightly deeper, more oxygenated waters.

4. The presence of discocyclinids and large rotaliids indicates deeper water and well oxygenated conditions, typical of Subassemblages IIIb and IIIc.

5. A spurious environmental signal might be given by Assemblage I. According to Hottinger (1983), coskinolinids are supposed to characterize very shallow environments whereas large nummulitids should proliferate in a deeper water.

6. The top parts of Subassemblages IIIa and IIc, characterized by corals and asterocyclinids, seem to indicate high water energy; this interpretation is also supported by the occurrence of worn specimens and rounded pebbles. In particular, Subassemblage IIc shows evidence of an admixture of different environments: from a restricted lagoonal environment, as indicated by the presence of Istriloculina; to a lagoonal but less restricted environment, as indicated by the presence of alveolinids; to slightly deeper open-marine environments, as indicated by the occurrence of Nummulites, asterocyclinids, and corals. This admixture suggests resedimentation and reworking of possibly older layers (see Table 1).

7. Lower levels of water energy, possibly in deeper water, may be reflected by Assemblage III (top part of IIIc and IIIb), which is dominated by encrusting red algae and occasional by rhodoliths.

8. In Subassemblage Ila, levels enriched in echinoderm fragments and rare large foraminifers may represent a more open-marine episode (storm deposit?).

\section{EVOLUTION OF LIMALOK CARBONATE PLATFORM}

The Limalok volcanic island subsided and was flooded in the early late Paleocene under shallow-marine conditions, a finding corroborated by the occurrence of calcareous nannofossils at the very base of the shallow-water succession. However, a substantial carbonate platform became established only in the latest Paleocene with a relatively deep-water environment covering the edifice (Subassemblage IIIc). Red algae appear as the pioneer colonizers of the muddy substrate, which rapidly was fully colonized (Subassemblage IIIb). The platform continued to grow, and lagoonal facies were deposited under oxygenated conditions in the center of the platform. The lagoonal facies are alternatively represented by biotopes rich in green algae and miliolids. After a reworking episode (Subassemblage IIc), a lagoonal environment was established in the center of the platform for most of the early Eocene. Conditions fluctuated from very restricted (top of Subassemblage IIc), to more oxygenated and possibly deeper (Subassemblage $\mathrm{IIb}$ ), as indicated by the abundant alveolinids, to again alternating from more to less restricted (Subassemblage IIa). Few minor episodes of more oxygenated, possibly deeper conditions interrupted this monotonous trend (abundance of echinoderm debris, rare planktonic foraminifers, and rare Nummulites).

The numerous nummulitids occurring at the top of the carbonate succession (Assemblage I) indicate that water depth over the center of the platform again markedly deepened.

Shortly after its demise in the early middle Eocene, the Limalok platform sunk quickly below the photic zone. The middle Eocene calcareous nannofossils (Zone CP13) and the slightly younger, welldiversified planktonic foraminifer assemblages (Zone P14) recorded from the capping Mn crust indicate that, shortly after the cessation of 
the shallow-water carbonate sedimentation, Site 871 was under an open-marine, oceanic environmental regime. The hiatus associated with the disconformity between the carbonate platform and the condensed pelagic sediments can be estimated as not exceeding 3-4 m.y., according to the time scale of Berggren et al. (1985).

\section{TAXONOMIC NOTES}

\section{Alveolina (Alveolina) ilerdensis Hottinger Plate 2, Fig. 1}

Remarks: It is the most abundant species. Several specimens not precisely cut through the embryonic chamber are grouped as Alveolina (Alveolina) sp. aff. A. ilerdensis (Plate 2, Figs. 2 and 6B) $3-9 \mathrm{~cm}$

ccurrence: Samples 144-871C-20R-1, 113-118 cm, through -19R-1,

$$
\begin{gathered}
\text { Alveolina (Alveolina) sp. aff. A. sakaryaensis Sirel } \\
\text { Plate 2, Figs. 3A, 6A, and } 7
\end{gathered}
$$

Remarks: Several specimens, variously oriented, may belong to $A$. sakaryaensis Sirel for the rather coarse architecture in respect to Alveolina moussoulensis.

Occurrence: Samples 144-871C-20R-1, 13-17 cm, and -19R-1, 4-10 cm

Alveolina (Alveolina) pinguis Hottinger

Plate 2, Fig. 9

Remarks: This species is represented by a single specimen.

Occurrence: Sample 144-871C-15R-1, 15-20 cm

\section{Alveolina (Alveolina) $\mathrm{sp}$}

Plate 2, Fig. 5

Remarks: Several specimens show architectural characters close to $A$ aragonensis Hottinger. The imprecise cuts prevent specific identification.

Occurrence: Samples 144-871C-20R-1, 113-118 and 21-25 cm

\section{Alveolina (Alveolina) sp. 2}

Plate 2, Fig. 8

Remarks: Few specimens resemble A. subpyrenaica Leymerie, but they display coarser architecture, larger size and different diameter/axis ratio than A. subpyrenaica.

Occurrence: Sample 144-871C-19R-1, 9-13 cm

\section{Alveolina (Alveolina) sp. 3}

Plate 2, Fig. 4

Remarks: Few specimens show some similarities to A. canavarii Checchia-Rispoli. The imprecise cuts prevent specific identification.

Occurrence: Samples 144-871C-20R-1, 21-25 cm (acetate peel), and $-20 \mathrm{R}-1,13-17 \mathrm{~cm}$

$$
\begin{gathered}
\text { Alveolina (Glomalveolina) sp. } \\
\text { Plate 1, Fig. } 6
\end{gathered}
$$

Remarks: A single, poorly preserved specimen shows the irregular inner coils typical of the subgenus Glomalveolina. The poor preservation prevents specific identification.

Occurrence: Sample 144-871C-21R-1, 72-77 cm

\section{Alveolina sp.}

Plate 1, Fig. 4

Remarks: Two specimens show a prominent flosculinization, but the imprecise cuts prevent specific identification.

Occurrence: Samples 144-871C-26R-1, 4-10 cm, and -25R-1, 18-28 cm

$$
\text { Coleiconus elongatus (Cole) }
$$

Plate 3, Fig. 3; Plate 4, Figs. 5 and 6

Remarks: This species, previously included in the genus Coskinolina, was demonstrated to belong to the new genus Coleiconus by Hottinger and Drobne (1980),
Occurrence: Samples 144-871C-3R-CC, 12-18 cm; -2R-1, "cuttings"; and -2R-1, 51-54 and 44-50 cm. Samples 144-871B-16X-CC, "cuttings," and $-16 \mathrm{X}-\mathrm{CC}, 15-18 \mathrm{~cm}$

$$
\text { Discocyclina sp. cf. D. barkeri Vaughan and Cole }
$$

Plate 4, Figs. 1-3

Remarks: Several specimens occur at the bottom of the carbonate platform succession either in thin section or as isolated specimens. The nepionic characters appear very close to those of $D$. barkeri described from the Caribbean region.

Occurrence: Samples 144-871C-32R-1, "cuttings"; -32R-1, 16-20 cm; and -30R-1, "cuttings"

\section{Guembelitrioides higginsi (Bolli) group}

Remarks: A single specimen with a high spire was attributed to this group. Occurrence: Sample 144-871C-8R-1, 21-25 cm

$$
\begin{aligned}
& \text { Nummulites sp. cf. } N \text {. deserti De la Harpe, } 1883 \\
& \text { Plate 1, Figs. 7A, 8A, and } 9
\end{aligned}
$$

Nummulites deserti De La Harpe, Schaub 1981, p. 74, pl. 1, figs. 1-31

Material: Some axial and oblique sections of mainly macrospheric forms. Thickness: $1 \mathrm{~mm}$; diameter of the macrosphere $=1 \mathrm{~mm} ; 3$ whorls in $1-\mathrm{mm}$ radius; large central "pillar"

Occurrence: Samples 144-871C-21R-1, 72-77 cm, and -21R-1, 17-20 cm

$$
\text { Nummulites sp. cf. laevigatus (Bruguière, 1792) }
$$$$
\text { Plate 3, Figs. 2, 4A, and } 5
$$

Nummulites laevigatus (Bruguière), Schaub 1981, p. 171, pl. 60, figs. 18-31 and 38-44

Nummulites laevigatus (Bruguière), Kleiber 1991, pl. 1, fig. 25; pl. 3, fig. 28.

Material: One axial section of microspheric form; few axial sections of macrospheric form.

Macrospheric form: Thickness $=1.3 \mathrm{~mm}$; diameter of the macrosphere $=0.4-0.5 \mathrm{~mm} ; 3$ whorls in $1.6-\mathrm{mm}$ radius; several small "pillars"

Microspheric form: Thickness $=3 \mathrm{~mm}$; 11 whorls in 5.3-mm radius; several small "pillars"

Occurrence: Samples 144-871C-2R-1, 51-54 cm, and -2R-1, 44-50 cm

\section{Nummulites nitidus group}

Figure 3

Nummulites sp. aff. N. nitidus Schaub 1981, p. 147, pl. 42, figs. 48-49; pl. 43, figs. $1-4$; tab. 11, fig. i

Material: A few isolated specimens of macrospheric form; only one specimen could be opened owing to the strong recrystallization of the inner whorls.

Thickness: $1.8 \mathrm{~mm}$; diameter of macrosphere $=0.22 \mathrm{~mm} ; 3$ whorls in 0.9 -mm radius; large central "pillar"

Occurrence: Section 144-871C-9R-1, "cuttings"

\section{ACKNOWLEDGMENTS}

The authors are indebted to the Ocean Drilling Program for inviting two of them (IPS and AAV) to participate on Leg 144. The authors would like to thank all the scientists involved in the study of Limalok Guyot and the technicians who prepared the thin sections and took the burden of collecting even the most microscopic chips of our poor material. Our warm thanks go also to E. Erba, who made the acetate peels, to L. Hottinger and K. Drobne for the careful and stimulating review of this paper, and to $\mathrm{C}$. Corselli for the helpful discussion on paleoecology of shallow-water organisms. G. Chiodi and C. Malinverno, both from the University of Milan, printed the photomicrographs and made some new thin sections, respectively. This research was financially supported by the Consiglio Nazionale delle Ricerche, Grant to IPS and Grant for ODP Research Program to M.B. Cita. 


\section{REFERENCES $*$}

Berggren, W.A., Kent, D.V., and Flynn, J.J., 1985. Jurassic to Paleogene: Part 2. Paleogene geochronology and chronostratigraphy. In Snelling, N.J. (Ed.), The Chronology of the Geological Record. Geol. Soc. London Mem., 10:141-195.

Drobne, K., 1977. Aléolines Paléogènes de la Slovenie et de l'Istrie. Mem. Suisses Palaeontol., 99.

Ellis, B.F., and Messina, A.R., 1967. Catalogue of Index Foraminifera: New York (American Museum of Natural History). Nat. Hist.)

Hottinger, L., 1960. Recherches sur les Alvéolines du Paléocène et de l'Eocène. Mem. Suisses Palaeontol., 75/76.

- 1983. Processes determining the distribution of larger Foraminifera in space and time. Utrecht Micropaleontol. Bull., 30:239-253.

Hottinger, L., and Drobne, K., 1980. Early Tertiary conical imperforate Foraminifera. Razprave Slov. Akad. Znanosti Umetnosti, 23:189-276.

-1988 . Tertiary Alveolinids: problems linked to the conception of species. Rev. Palaeobiol., Benthos '86 Spec. Vol., 2:665-681.

Kleiber, G.W., 1991. Nummuliten der palaeogenen Tethys in Axialschnitten. Mikropalaeontolog. Mitt., 9.

Less, G., 1987. Paleontology and stratigraphy of the European Orthophragmina. Geol. Hungar, 51.

Okada, H., and Bukry, D., 1980. Supplementary modification and introduction of code numbers to the low-latitude coccolith biostratigraphic zonation (Bukry, 1973; 1975). Mar. Micropaleontol., 5:321-325.

Premoli Silva, I., and Brusa, C., 1981. Shallow-water skeletal debris and larger foraminifers from Deep Sea Drilling Project Site 462, Nauru Basin, western equatorial Pacific. In Larson, R.L., Schlanger, S.O., et al., Init. Repts. DSDP, 61: Washington (U.S. Govt. Printing Office), 439-473.

Premoli Silva, I., Haggerty, J., Rack, F., et al., 1993. Proc. ODP, Init. Repts., 144: College Station, TX (Ocean Drilling Program).

Reiss, Z., and Hottinger, L., 1984. The Gulf of Aqaba: Ecological micropaleontology. In Billings, W.D., Golley, F., et al. (Eds.), Ecological Studies: Berlin (Springer-Verlag).

Schaub, H., 1981. Nummulites et Assilines de la Téthys paléogène: taxinomie, phylogenèse et biostratigraphie. Mem. Suisses Palaeontol., 104-106.

Schlanger, S.O., Campbell, J.F., and Jackson, M.W., 1987. Post-Eocene subsidence of the Marshall Islands recorded by drowned atolls on Harrie and Sylvania guyots. In Keating, B.H., Fryer, P., Batiza, R., and Boehlert, G.W. (Eds.), Seamounts, Islands, and Atolls. Geophys. Monogr., Am. Geophys. Union, 43:165-174.

Toumarkine, M., and Luterbacher, H., 1985. Paleocene and Eocene planktic foraminifera. In Bolli, H.M., Saunders, J.B., and Perch-Nielsen, K. (Eds.), Plankton Stratigraphy: Cambridge (Cambridge Univ. Press), 87-154.

White, M.R., 1992. On species identification in the foraminiferal genus Alveolina (late Paleocene-middle Eocene). J. Foraminiferal Res., 22:5270 .

\footnotetext{
- Abbreviations for names of organizations and publications in ODP reference lists follow the style given in Chemical Abstracts Service Source Index (published by American Chemical Society).
}

Date of initial receipt: 1 February 1994

Date of acceptance: 15 September 1994

Ms 144SR-012 

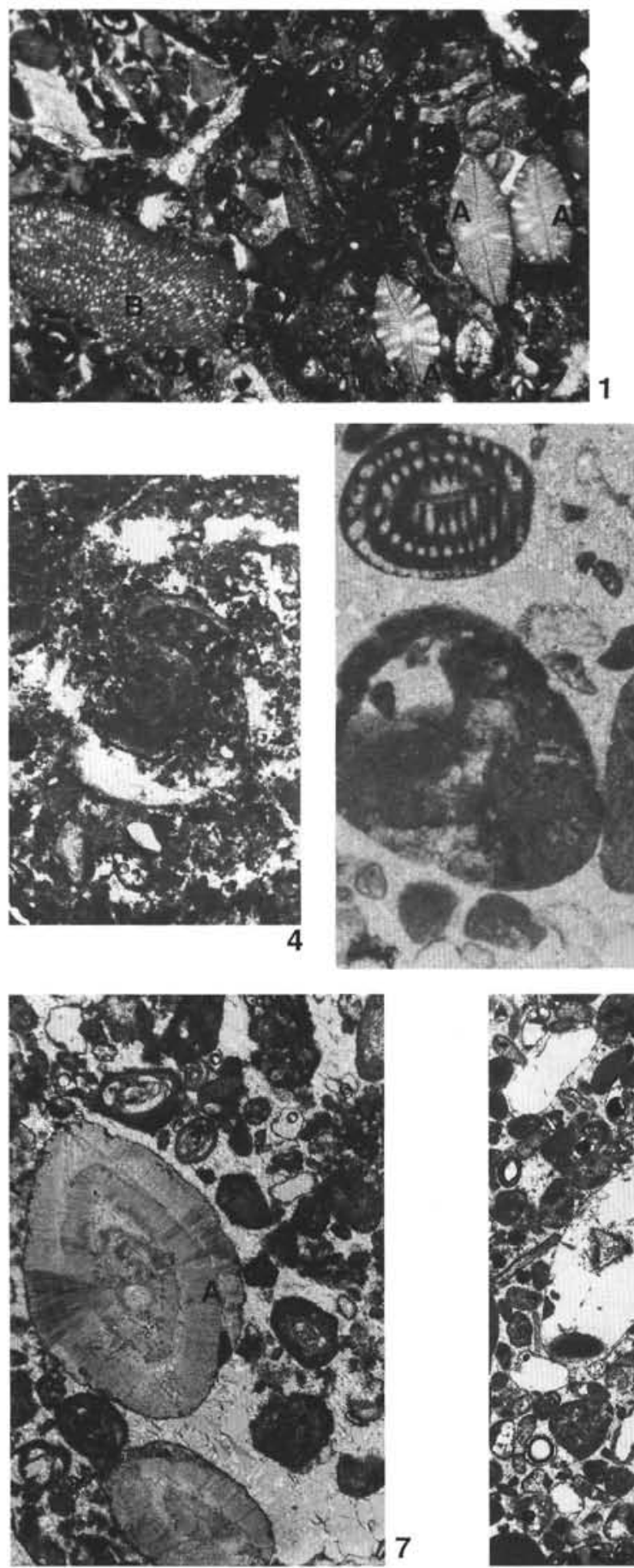
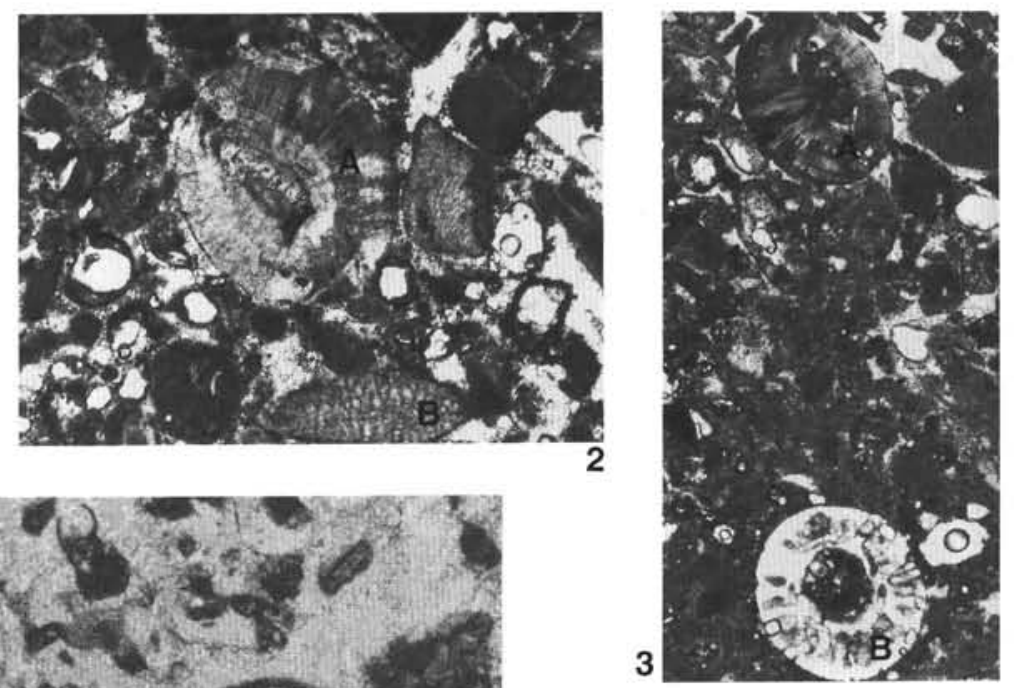

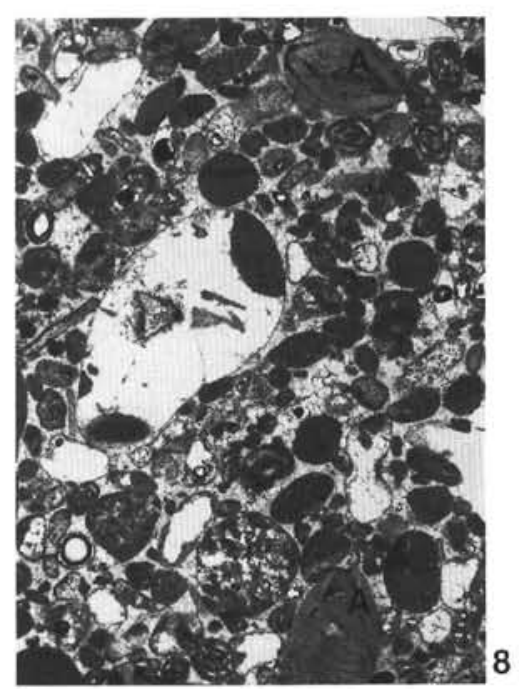

5
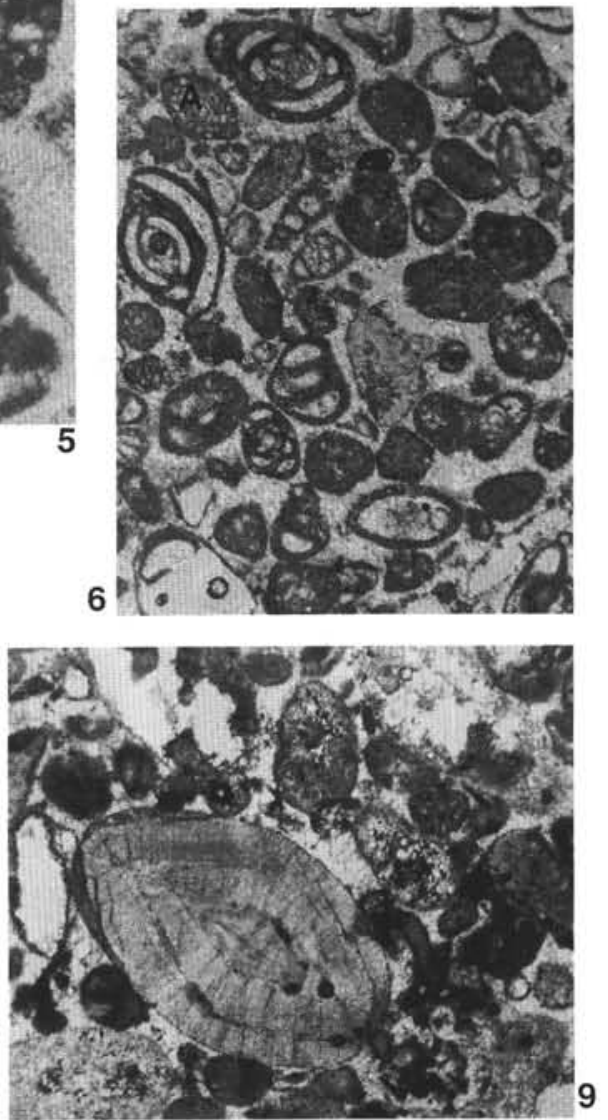

Plate 1. 1. Bioclastic packstone with (A) Discocyclina ssp., abundant corallinacean algae, miliolids, and other small foraminifers; and (B) Parachaetetes?. Sample 144-871C-32R-1, 16-20 cm, 8×. 2. Bioclastic packstone with (A) large rotaliid, oblique section, and (B) Asterocyclina sp. Sample 144-871C-29R-1, 16-21 cm, 12×. 3. Bioclastic packstone with (A) large rotaliid, oblique section, and (B) dasycladacean. Sample 144-871C-28R-1, 105-108 cm, 9x. 4. Bioclastic packstone with a specimen of Alveolina sp., strongly flosculinized. Sample 144-871C-25R-1, 18-28 cm, 10x. 5. Bioclastic packstone with several oblique sections of Alveolina sp. and miliolids. Sample 144-871C-21R-1, 130-136 cm, 10×. 6. Bioclastic grainstone with miliolids, ostracods, and (A) Alveolina (Glomoalveolina) sp. Sample 144-871C-21R-1, 72-77 cm, 14×. 7. Bioclastic grainstone with miliolids and (A) Nummulites sp. cf. N. deserti, axial section. Sample 144-871C-21R-1, $72-77 \mathrm{~cm}, 13 \times$. 8. Bioclastic grainstone with miliolids and (A) Nummulites sp. cf. $N$. deserti, axial and oblique sections. Sample 144-871C-21R-1, 17-20 cm, 5x. 9. Bioclastic grainstone with Nummulites sp. cf. $N$. deserti, axial section. Sample 144-871C-21R-1, 17-20 cm, 12X. 

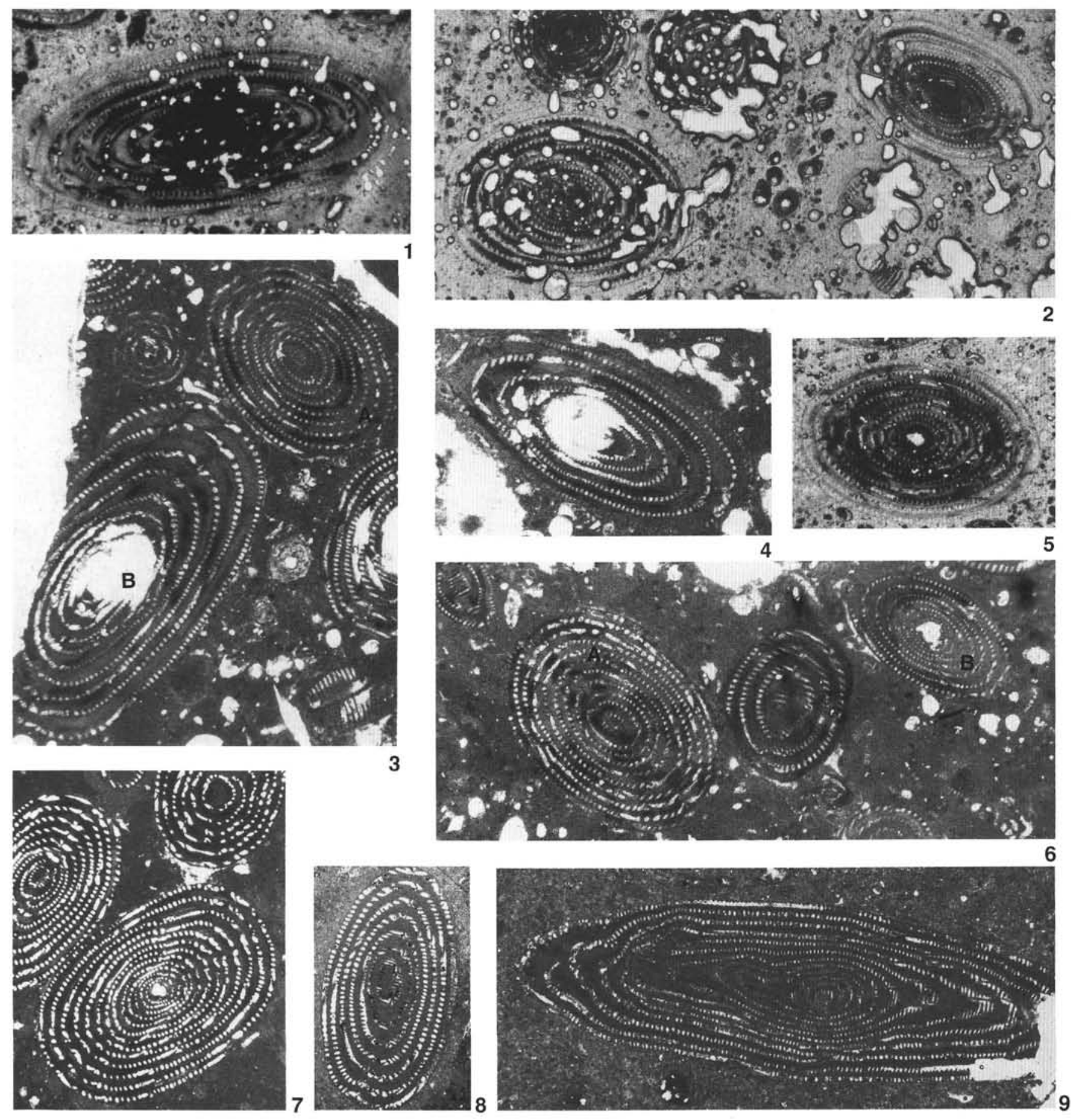

Plate 2. All photomicrographs (magnification 5x). 1. Alveolina (Alveolina) ilerdensis, axial section. Sample 144-871C-20R-1, 113-118 cm, acetate peel. 2. Alveolina (Alveolina) sp. aff. A. ilerdensis, axial and oblique sections. Sample 144-871C-20R-1, 113-118 cm, acetate peel. 3. Bioclastic mudstone with (A) Alveolina (Alveolina) sp. aff. A. sakaryaensis, slightly oblique axial section; and (B) Alveolina sp. 3, axial section. Sample 144-871C-20R-1, 13-17 cm. 4. Alveolina sp. 3, axal section. Sample 144-871C-20R-1, 13-17 cm. 5. Alveolina sp. 1, axial section. Sample 144-871C-20R-1, 113-118 cm, acetate peel. 6. Bioclastic mudstone with (A) Alveolina (Alveolina) sp. aff. A. sakaryaensis, slightly oblique axial section; and (B) Alveolina (Alveolina) sp. aff. A. ilerdensis, axial section. Sample 144-871C-20R-1, 13-17 cm. 7. Alveolina (Alveolina) sp. aff. A. sakaryaensis, slightly oblique axial sections. Sample 144-871C-19R-1, 4-10 cm. 8. Alveolina (Alveolina) sp. 2, oblique axial section. Sample 144-871C-19R-1, 9-13 cm. 9. Alveolina (Alveolina) pinguis, slightly oblique axial section. Sample 144-871C-15R-1, 15-20 cm. 

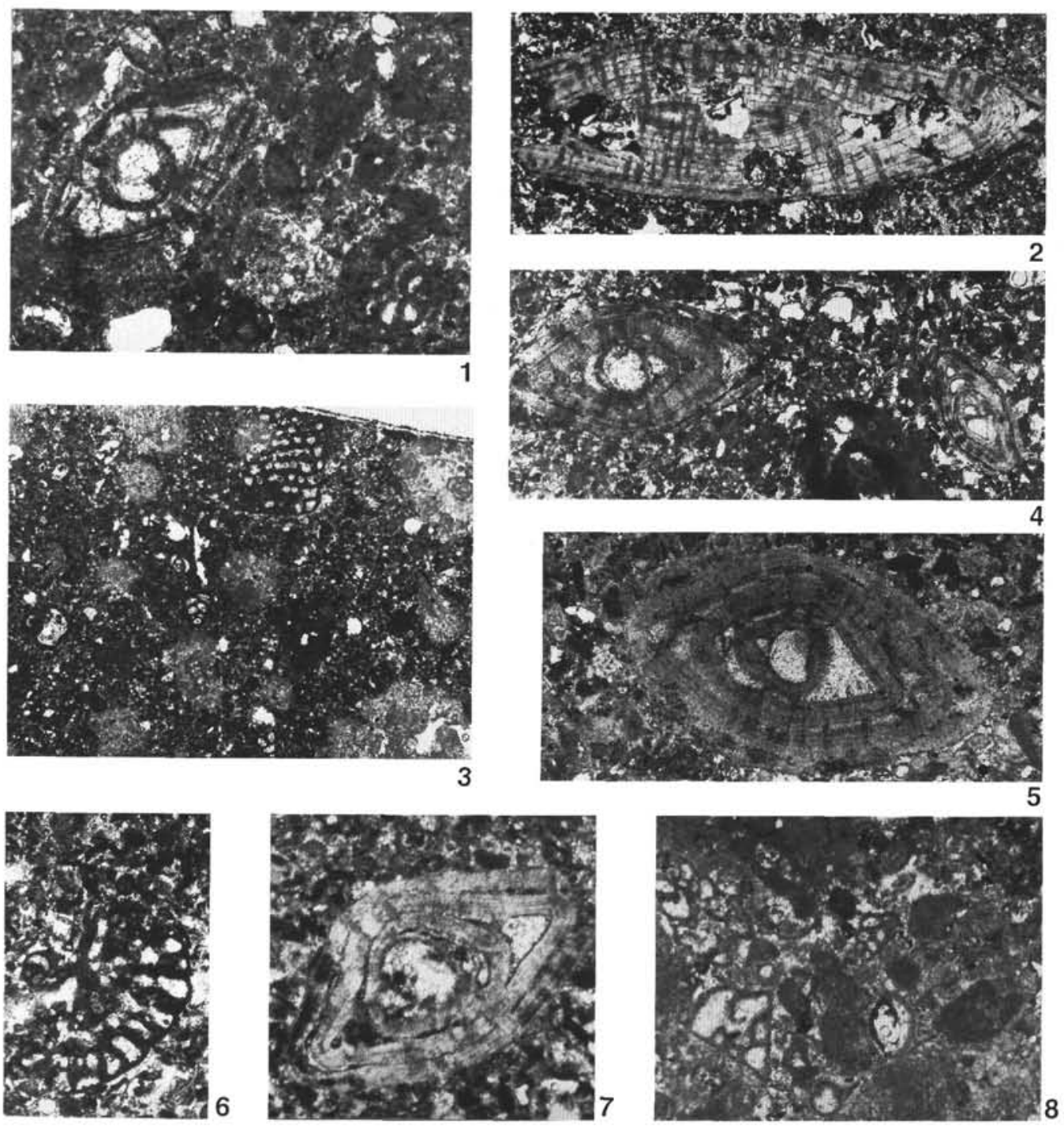

Plate 3. 1. Bioclastic packstone with small foraminifers and Nummulites sp., axial section, Form A. Sample 144-871C4R-1, 14-19 cm, 21×. 2. Nummulites sp. cf. N. laevigatus, axial section, Form B. Sample 144-871C-2R-1, 51-54 cm, $8 \times$ 3. Bioclastic packstone with Coleiconus elongatus, oblique axial section, and small foraminifers. Sample 144-871C3R-CC, 12-18 cm, 17×. 4. Bioclastic packstone with (A) Nummulites sp. $\mathrm{cf}$. N. laevigatus, axial section, Form A, (B) Nummulites sp., axial oblique section. Sample $144-871 \mathrm{C}-2 \mathrm{R}-1,51-54 \mathrm{~cm}, 15 \times$. 5. Bioclastic packstone with Nummulites sp. cf. $N$. laevigatus, axial section, Form A. Sample $144-871 \mathrm{C}-2 \mathrm{R}-1,44-50 \mathrm{~cm}, 32 \times$. 6. Bioclastic packstone with Coleiconus elongatus, oblique section, and small foraminifers. Sample 144-871C-2R-1, 51-54 cm, 27×. 7. Nummulites sp., axial section, Form A. Sample 144-871C-2R-1, 51-54 cm, 28×. 8. Bioclastic packstone with abundant small foraminifers including valvulinids and verneuilinids. Sample $144-871 \mathrm{C}-2 \mathrm{R}-1,11-14 \mathrm{~cm}, 27 \mathrm{X}$. 

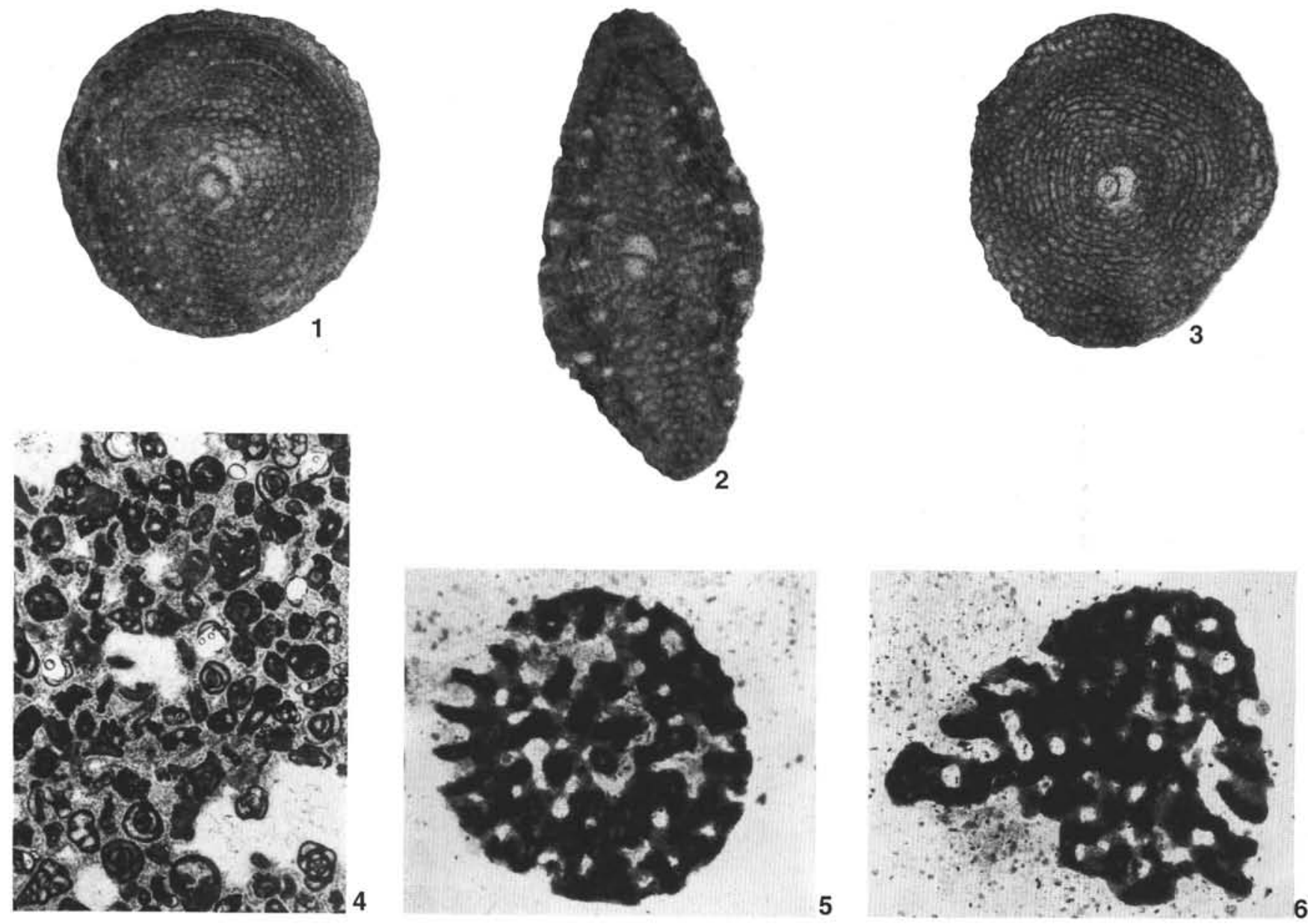

Plate 4. 1. Discocyclina sp. cf.D. barkeri, equatorial section. Section 144-871C-32R-1, “cuttings," 18×. 2. Discocyclina sp. cf. D. barkeri, oblique axial section. Section 144-871C-32R-1, "cuttings," 22×. 3. Discocyclina sp. cf. D. barkeri, equatorial section. Section 144-871C-32R-1, "cuttings," 18×. 4. Bioclastic grainstone with miliolids and other small foraminifers. Sample 144-871C-4R-1, 48-52 cm, 5×. 5. Coleiconus elongatus, transverse section. Section 144-871B16X-CC, "cuttings," 22×. 6. Coleiconus elongatus, oblique axial section. Section 144-871B-16X-CC, "cuttings," 22×. 